\title{
Antidiabetic Effect of Cleome droserifolia Aerial Parts: Lipid Peroxidation-Induced Oxidative Stress in Diabetic Rats
}

\author{
EM.B. EL NAGGAR ${ }^{1}$, L. BARTOŠÍKOVÁ ${ }^{1}$, M. ŽEMLIČKA ${ }^{2}$, E. ŠVAJDLENKA ${ }^{2}$, M. RABIŠKOVÁ ${ }^{3}$, \\ V. STRNADOVÁ ${ }^{1}, J^{\prime}$. NEČAS ${ }^{1}$ \\ ${ }^{1}$ Department of Human Pharmacology and Toxicology \\ ${ }^{2}$ Department of Natural Drugs, ${ }^{3}$ Department of Drug Technology \\ Faculty of Pharmacy, University of Veterinary and Pharmaceutical Sciences, Brno, Czech Republic
}

Received December 9, 2004

Accepted August 30, 2005

\begin{abstract}
El Naggar EM.B., L. Bartošíková, M. Žemlička, E. Švajdlenka, M. Rabišková, V. Strnadová J. Nečas: Antidiabetic Effect of Cleome droserifolia Aerial Parts: Lipid PeroxidationInduced Oxidative Stress in Diabetic Rats. Acta Vet. Brno 2005, 74: 347-352.

The present study aims to investigate the antidiabetic as well as the effect on lipid peroxidation of three different doses $(50,100$, and $200 \mathrm{mg} / \mathrm{kg})$ of Cleome droserifolia aerial parts methanolic extract in comparison with glibenclamide in alloxan-induced diabetic rats.

Forty-two rats (35 diabetic and 7 normal) were included in this study. Oral administration of 100 and $200 \mathrm{mg} / \mathrm{kg}$ of the methanolic extract for 3 weeks significantly $(P<0.05)$ restored the blood glucose level, plasma malondialdehyde and urine sugar to near the physiological values whereas the effect of $50 \mathrm{mg} / \mathrm{kg}$ was not significant.

Furthermore, from the HPLC chromatograms, we identified the presence of three flavonoids (quercetin, kaempferol, and isorhamnetin) together with three phenolic acids (sinapinic acid, ferulic acid and 4-coumaric acid) which may explain at least in part some of the antidiabetic and antioxidative properties observed in this study.
\end{abstract}

Antidiabetic, antiperoxidative, malondialdehyde, flavonoids, phenolic acids, HPLC, alloxan, diabetes, rats

Since the availability of insulin and oral hypoglycemic drugs, traditional drugs for diabetes have almost declined. Sulfonylurea and metformin are valuable treatments for hyperglycemia in NIDDM but they are often unable to lower glucose concentrations to within the normal range, or to reinstate a normal pattern of glucose homeostasis (Bailey et al. 1998).

The use of these drugs is restricted by their pharmacokinetic properties, secondary failure rates, and accompanying side effects (Melander et al. 1988; De Smet 1997) and the World health organization expert committee on diabetes has listed as one of its recommendations that traditional methods of treatment for diabetes should be further investigated (WHO Expert Committee).

Despite efforts to control blood glucose, tissue and organ damage are cumulative over many years in most diabetic patients. Since varying degrees of hyperglycemia are virtually unavoidable in diabetes, these patients should in theory benefit from supplementation with potent direct antioxidants.

However, hyperglycemia-induced oxidative stress ultimately leads to tissue damage has advanced considerably in recent years. Effective therapeutic strategies to prevent or delay the development of this damage remain limited and the American Diabetes Association recommended that antioxidant therapy needs to be improved either older antioxidants such as vitamin E, L. A. (lipoic acid), and NAC ( $N$-acetyl-L-cysteine) needs to be reformulated, or newer antioxidants need to be identified (Evans et al. 2003).

Plants constitute an important source of active natural products, which differ widely in terms of structure and biological properties. They have a remarkable role in the traditional medicine

Address for correspondence:

PharmD. El-Moataz Bellah El-Naggar

Department of Human Pharmacology and Toxicology

Pharmaceutical Faculty, Veterinary and Pharmaceutical University,

Palackého 1-3, 61242 Brno, Czech Republic.
Phone: +420541562724

Fax:+420 541240605

E-mail: elmoatazpharm@hotmail.com

http://www.vfu.cz/acta-vet/actavet.htm 
in different countries. The protective effects of plant products are due to the presence of several components, which have distinct mechanisms of action; some of them are enzymes and proteins and others are low molecular weight compounds such as vitamins, carotenoids, flavonoids (Zhang and W ang 2002), anthocyanins and other phenolic compounds (S anchez-Moreno et al. 1998). It is of interest in the context of flavonoid chemistry that attempts to "improve upon nature" have generally failed. This review considers the current status of scientific and medical research in the use of traditional plant treatment for diabetes mellitus.

More than 400 different plant and plant extracts have almost been described for the treatment of diabetes throughout the world, but only a small number of these have received scientific and medical evaluation to assess their efficacy (De Smet 1997). Among these plants the Egyptian plant, Cleome droserifolia, which is currently used in the Egyptian folklore medicine for the treatment of diabetes mellitus. Meanwhile, the lack of scientific evidence about its efficacy initiated the need of this study, in order to justify its usage or to enlighten the users about its inefficacy.

This study and its course were approved and monitored by the Ethical Committee of the University of Veterinary and Pharmaceutical Sciences. The state of health of all animals was regularly examined several times a day both during the period of the acclimation of the animals and during the whole course of the experiment by the working team whose members are holders of the Certificate on Professional Competence issued by the Central Commission for the Animal Protection Pursuant to $\S 17$ of the Act on Protection of Animals against Cruelty (No. 246/1992 Coll.) of the Czech National Council.

\section{Materials and Methods}

Cleome droserifolia aerial parts were collected from Arish, North Sinai, Egypt, identified by the Department of Botany, Faculty of Science, Alexandria University. The plant extract was prepared by the Pharmacognosy Department, Faculty of Pharmacy, Veterinary and Pharmaceutical University, Brno.

Extraction was performed in methanol using Soxhlet extractor until complete exhaustion of the plant material. Methanol then was removed via rotavapour at $40-50{ }^{\circ} \mathrm{C}$ under reduced pressure. Extracted yields were determined from the original weight of the ground sample before extraction over the weight of extract following rotoevaporation.

Three different concentrations of the extract were prepared at a doses of $(50 \mathrm{mg} / \mathrm{kg}, 100 \mathrm{mg} / \mathrm{kg}$ and $200 \mathrm{mg} / \mathrm{kg}$ ) using DMSO and water in a ratio of $(0.2: 0.8)$ respectively.

This study was performed on male laboratory rats of the Wistar SPF line (AnLab s.r.o., Brno), of identical age (4 months) and comparable weight $(250 \pm 15 \mathrm{~g})$. The animals were placed individually in glass metabolic cages, fed a standard diet (Diet for small laboratory animals SPF Ml) and given water ad libitum. After the time necessary for acclimation, rats were injected intraperitoneally with freshly prepared solution of alloxan monohydrate in normal saline at a dose of $150 \mathrm{mg} / \mathrm{kg} \mathrm{BW}$ (L.Al-Shama ony et al. 1994).

Because alloxan is capable of producing fatal hypoglycemia as a result of massive pancreatic insulin release, rats were treated with $20 \%$ glucose solution $(5-10 \mathrm{ml})$ orally after $6 \mathrm{hr}$. The rats then were kept for the next $24 \mathrm{hr}$ on $5 \%$ glucose solution bottles in their cages to prevent hypoglycemia (Gupta et al. 1984).

After 2 weeks, rats with moderate diabetes that exhibited glycosuria and hyperglycemia (i.e. blood glucose concentration 11-17 mmol/l) were included in the experiment.

Forty-two rats (35 diabetic and 7 normal rats) were included. Diabetic rats were divided into 5 groups (each include seven rats).

Group 1: Normal untreated rats

Group 2: Diabetic control rates received $1 \mathrm{ml}$ of the solvent.

Group 3: Diabetic rats received $50 \mathrm{mg} / \mathrm{kg}$ body weight

Group 4: Diabetic rats received $100 \mathrm{mg} / \mathrm{kg}$ body weight

Group 5: Diabetic rats received $200 \mathrm{mg} / \mathrm{kg}$ body weight

Group 6: Diabetic rats received glibenclamide $(600 \mu \mathrm{g} / \mathrm{kg}$ body weight $)$

The plant extracts and the drug glibenclamide were given once daily using an intragastric tube for 3 weeks in a total volume of $1 \mathrm{ml}$ of the solvent. Fasting blood glucose level was measured regularly using glucometer (before, during and after the experiment). Urine was checked daily for the presence of glucose using Glucophan urine strips (Pliva- Lachema Czech Republic).

At the end of the experiment, the animals were deprived of food overnight, anaesthetized by the intramuscular injection of $\left(0.5 \mathrm{ml} 2 \%\right.$ Rometar $^{\mathbb{B}}+10 \mathrm{ml} 1 \%$ Narkamon $\left.^{\circledR}\right)$ in a dose of $0.5 \mathrm{ml} / 100 \mathrm{~g}$ of the body weight and then subsequently exsanguinated by blood collection from the left ventricle. Blood were collected in tubes containing 
potassium oxalate and sodium fluoride solution for the estimation of malondialdehyde spectrophotometrically using TBARs method (Kosugy et al. 1989).

For identification of some of the major components, High Performance Liquid Chromatography was performed using the methanolic extract before and after hydrolysis with $\mathrm{HCl}$. Spectra of the compounds identified were then compared with their standard spectra measured on the same method. The HPLC (HP 1100) system consists of quaternary pump, autosampler, thermostatic column compartment, diode array detector, fluorescence detector and electrochemical detector. The analytical column was C18 Supelcosil ABZ+ plus, $15 \mathrm{~cm}$ x $4.6 \mathrm{~mm}, 3 \mu \mathrm{m}$. Mobile phase consisted of two eluents, (A) acetonitrile and (B) $0.2 \%$ formic acid. Separation of compounds was carried out with gradient elution profile: $0 \mathrm{~min}, 10: 90 ; 36 \mathrm{~min}, 100: 0 ; 40 \mathrm{~min}, 100: 0$. Chromatography was performed at $30{ }^{\circ} \mathrm{C}$ with a flow-rate of $1.0 \mathrm{ml} / \mathrm{min}$, and detection was at $254 \mathrm{~nm}$ for DAD, at ex. $254 \mathrm{~nm}$, em. $410 \mathrm{~nm}$ for fluorescence detector and at $0.5 \mathrm{~V}$ for electrochemical detector.

The statistical analysis was performed using SPSS 10/windows. Student $t$-test was used to compare means of different variance. The statistical difference was considered as significant at $P<0.05$.

\section{Results}

Concentrations of blood glucose (mmol/l) and urine glucose are presented below.

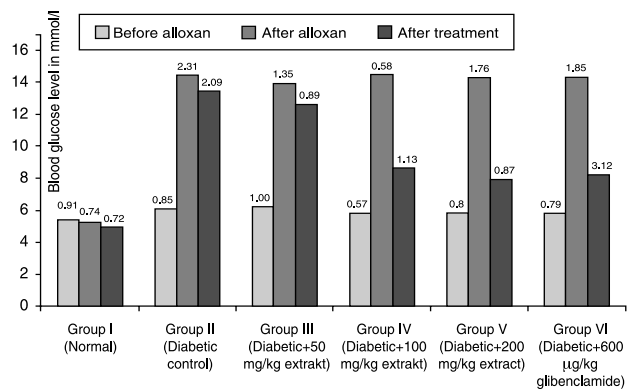

Fig. 1. Blood glucose levels [values are given as mean $(\mathrm{mmol} / \mathrm{l})$ in each group] of normal and experimental group's before and after alloxan administration, and after treatment with Cleome droserifolia methanolic extracts and glibenclamide for 3 weeks

Table 1. Changes in levels of blood and urine glucose of normal and experimental animals

\begin{tabular}{|c|c|c|c|c|c|}
\hline Experimental groups & $\begin{array}{c}\text { Blood } \\
\text { glucose } \\
\text { level before } \\
\text { alloxan }\end{array}$ & $\begin{array}{l}\text { Blood } \\
\text { glucose } \\
\text { level after } \\
\text { alloxan }\end{array}$ & $\begin{array}{l}\text { Blood } \\
\text { glucose } \\
\text { level after } \\
\text { treatment }\end{array}$ & $\begin{array}{c}\text { Paired } \\
\text { t-test }\end{array}$ & $\begin{array}{l}\text { Percent } \\
\text { Change in } \\
\text { blood } \\
\text { glucose }\end{array}$ \\
\hline Normal (intact group) & $5.44 \pm 0.91$ & $5.18 \pm 0.74$ & $4.92 \pm 0,72$ & Nonsignificant & - \\
\hline Diabetic control & $6.06 \pm 0.85$ & $\begin{array}{c}14.43 \pm 2.31 \\
(+++)\end{array}$ & $\begin{array}{c}13.40 \pm 2.09 \\
(+++)\end{array}$ & Nonsignificant & - \\
\hline Diabetic $+50 \mathrm{mg}$ of plant extract & $6.20 \pm 1.00$ & $\begin{array}{c}13.93 \pm 1.35 \\
(+++)\end{array}$ & $\begin{array}{c}12.63 \pm 0.89 \\
(+++)\end{array}$ & Nonsignificant & $(-5.74 \%)$ \\
\hline Diabetic $+100 \mathrm{mg}$ of plant extract & $5.80 \pm 0.57$ & $\begin{array}{c}14.47 \pm 0.58 \\
(+++)\end{array}$ & $\begin{array}{c}8.62 \pm 1.43 \\
(+)\end{array}$ & $\mathrm{P}<0.05$ & $(-35.67 \%)$ \\
\hline Diabetic $+200 \mathrm{mg}$ of plant extract & $5.80 \pm 0.80$ & $\begin{array}{c}14.33 \pm 1.76 \\
(+++)\end{array}$ & $\begin{array}{c}7.93 \pm 0.87 \\
(+)\end{array}$ & $\mathrm{P}<0.05$ & $(-40.82 \%)$ \\
\hline Diabetic + Glibenclamide $(600 \mathrm{mg} / \mathrm{kg})$ & $5.82 \pm 0.79$ & $14.28 \pm 1.85$ & $8.22 \pm 3.12$ & $\mathrm{P}<0.05$ & $(-38.65 \%)$ \\
\hline
\end{tabular}

Values are expressed as mean $(\mathrm{mmol} / \mathrm{l}) \pm \mathrm{S} . \mathrm{D}$.

Values in parentheses indicated the percentage lowering of blood glucose in comparison with diabetic control. Diabetic control was compared with normal: $P<0.05$.

Each experimental group was compared with its corresponding value before and after treatment: $P<0.05$.

Experimental groups were compared with diabetic control: $P<0.05$.

$(+++)$ indicates more than $1 \%$ glucose in urine and $(+)$ indicates traces 
Fasting blood glucose was significantly higher in alloxan diabetic rats as compared to control values using t-test at $0.05 \%$ level of significance $(P<0.05)$. The mean \pm S.D. of the control group was $5.18 \pm 0.74(\mathrm{mmol} / \mathrm{l})$, while that of the alloxan diabetic groups was $14.28 \pm 1.57(\mathrm{mmol} / \mathrm{l})$.

The administration of the extract (in the doses of $100 \mathrm{mg} / \mathrm{kg}$ and $200 \mathrm{mg} / \mathrm{kg}$ ) and glibenclamide to diabetic rats significantly restored the level of blood glucose to near normal level when compared with its corresponding value before and after treatment $(P<0.05)$ using paired t-test at $0.05 \%$ level of significance. They were also able to reduce the excretion of sugar in urine to a significant extent. The administration of the extract at dose of $50 \mathrm{mg} / \mathrm{kg}$ to diabetic rats did not show significant effect on both blood glucose and urine sugar levels. The percentage decrement of the fasting blood glucose level observed for glibenclamide, $100 \mathrm{mg} / \mathrm{kg}$ and $200 \mathrm{mg} / \mathrm{kg}$ of the extract after 21 days of oral administration were $38.65 \%$, $35.67 \%$ and $40.82 \%$, respectively.

Table 2 . Effect of Cleome droserifolia extracts and glibenclamide on the plasma malondialdehyde level $(\mathrm{mmol} / \mathrm{l})$ of experimental animals after treatment for 3 weeks

\begin{tabular}{|l|l|}
\hline \multicolumn{1}{|c|}{ Experimental groups } & MDA(mmol/l) \\
\hline Normal (intact group) & $0.98 \pm 0.70^{*}$ \\
Diabetic control & $3.40 \pm 0.93^{*}$ \\
Diabetic $+50 \mathrm{mg}$ of plant extract & $2.07 \pm 0.97 \mathrm{n.s}$ \\
Diabetic $+100 \mathrm{mg}$ of plant extract & $1.43 \pm 0.57^{*}$ \\
Diabetic $+200 \mathrm{mg}$ of plant extract & $1.11 \pm 0.13^{*}$ \\
Diabetic + Glibenclamide $(600 \mu \mathrm{g} / \mathrm{kg})$ & $1.29 \pm 0.49^{*}$ \\
\hline
\end{tabular}

Values are expressed as mean $(\mathrm{mmol} / \mathrm{l}) \pm \mathrm{S} . \mathrm{D}$.

Diabetic control was compared with normal: $* P<0.05$.

Experimental groups were compared with diabetic control: $* P<0.05$.

Values are statistically significant at $* P<0.05$ and n.s. (not significant) as compared with the respective control.

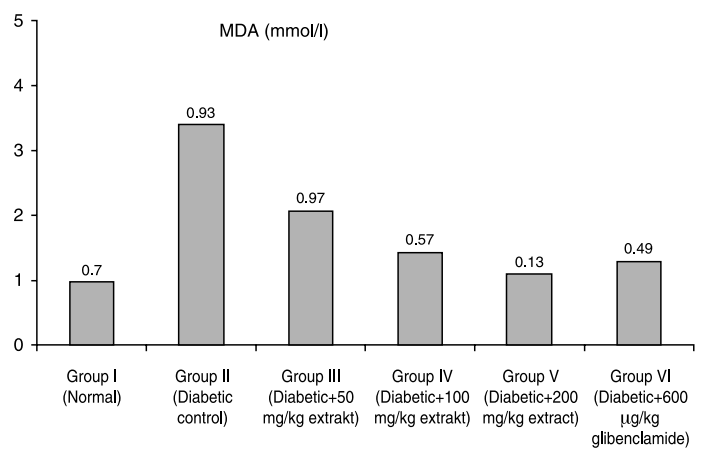

Fig. 2. Plasma MDA levels [values are given as mean $(\mathrm{mmol} / \mathrm{l})$ in each group] of normal and experimental groups after 21 days of treatment of the experimental animals with Cleome droserifolia methanolic extracts and glibenclamide

A marked increase in the level of MDA was observed in diabetic control rats as compared with normal group. Treatment with the methanolic extract at doses of (100 and $200 \mathrm{mg} / \mathrm{kg})$ and glibenclamide for 3 weeks significantly $(P<0.05)$ reduced the level of plasma MDA levels as compared to diabetic control. The extract at a dose of $50 \mathrm{mg} / \mathrm{kg}$ do not show significant difference. 
The HPLC chromatograms obtained from the methanolic extract before acidification (Plate III, IV) show that the major compounds have a typical flavonoids spectra and retention time similar to that of glycosides. After hydrolysis, we identified the peaks of quercetin, kaempferol and isorhamnetin as well as that of three phenolic acids sinapinic, ferulic and 4coumaric acid.

\section{Discussion}

The use of traditional medicine and medicinal plants in most developing countries, as a normative basis for the maintenance of good health, has been widely observed (Tiw ai and Madhusudan Rao 2002). Free radicals induced lipid peroxidation has been associated with a number of disease processes including diabetes mellitus (Feillet-Coudray et al. 1999). The present study was conducted to study the antidiabetic and the antiperoxidative activity of Cleome droserifolia in alloxan diabetic rats as well as to provide an introductory approach for the evaluation of its traditional preparation in order to scientifically validate the therapeutic preparation of this plant in the control of diabetes.

In all the experimental groups prior to alloxan administration, the basal levels of blood glucose of the rats were not significantly different. However, 14 days after alloxan administration, blood glucose levels were significantly higher in the rats selected for the study. The oral administration of Cleome droserifolia extract at the doses of $100 \mathrm{mg} / \mathrm{kg}$ and $200 \mathrm{mg} / \mathrm{kg}$ significantly decreases both blood glucose and urine sugar levels to near normal in alloxan diabetic rats. The percentage decrease in blood sugar level of the methanolic extract at the dose of $200 \mathrm{mg} / \mathrm{kg}$ was more significant than that of glibenclamide.

In agreement with previous studies (Kakkar et al. 1998), the induction of diabetes in rats with alloxan resulted in an increase in lipid peroxidation (TBARS), an indirect evidence of intensified free radical production. Most of the tissue damage is consider being free radicals mediated by attacking membranes through peroxidation of unsaturated fatty acids. The present finding indicates significantly increased lipid peroxidation in rats exposed to alloxan and its attenuation by Cleome droserifolia extract oral administration at the doses of 100 and $200 \mathrm{mg} / \mathrm{kg}$. The antiperoxidative effect of the methanolic extract at the dose of $200 \mathrm{mg} / \mathrm{kg}$ shows more significant effect than that of glibenclamide.

The primary identification of the previously mentioned glycosidic flavonoids and their coexistence with these phenolic acids may explain at least in part some of the antidiabetic and antioxidative properties of this extract. Our findings are in agreement with those reported by (Fushiya et al. 1999). Who was able to identify, separate and study the suppressive effect of two new flavonoids from Cleome droserifolia on the NO (Nitric oxide) production in activated macrophages in vitro.

In conclusion, the methanolic extracts of Cleome droserifolia at the doses of 100 and 200 $\mathrm{mg} / \mathrm{kg}$ were found to exhibit a significant antidiabetic and antiperoxidative activity in alloxan diabetic rats. Such effects can be explained at least in part by the presence of the previously mentioned flavonoids and phenolic acids. Further, pharmacological studies and phytochemical investigations are in progress in our laboratories in order to isolate, purify, elucidate and explore the mechanism of action of the active ingredient(s) or at least the most active purified fraction responsible for the antidiabetic and antiperoxidative activity observed in this study.

\section{Antidiabetický efekt nadzemních částí Cleome droserifolia u diabetických potkanů za oxidativního stresu}

Cílem předložené studie bylo sledování antidiabetického a antioxidačního efektu 3 různých dávek (50,100 a $200 \mathrm{mg} / \mathrm{kg}$ ) methanolického extraktu z nadzemních částí Cleome 
droserifolia na laboratorní potkany s alloxanem navozeným diabetes mellitus. Bylo použito 42 potkanů a účinek byl porovnáván s glibenklamidem. Perorální podávání methanolického extraktu jednou denně v dávkách 100 a $200 \mathrm{mg} / \mathrm{kg}$ po dobu 3 týdnů signifikantně $(P<0.05)$ snižuje hladinu glukosy a malondialdehydu v plazmě a glukosy v moči. Dávka extraktu 50 mg/kg nevykázala signifikantní vliv ani na jeden ze sledovaných parametrů.

Pomocí HPLC byly v methanolickém extraktu Cleome droserifolia identifikovány 3 flavonoidy (kvercetin, kempferol a isorhamnetin) a 3 fenolické kyseliny (sinapová, ferulová a 4-kumarová), které jsou zřejmě alespoň částečně zodpovědné za zjištěnou antidiabetickou a antioxidační aktivitu.

\section{Acknowledgement}

This work was supported by Research intention No. 163700003 and No. NL 7455-3 IGA Ministry of Health, Czech Republic.

\section{References}

BAILEY CJ, NATTRASS M 1998: Non-insulin dependent diabetes mellitus: treatment with metformin. In: NATTRASS M, HALE PJ: Clinical Endocrinology and Metabolism. Baillière-Tindall, London, pp. 455-476.

DE SMET PA 1997: The Role of Plant-Derived Drugs and Herbal Medicines in Healthcare. Drug 54: 801-840

EVANS JL, GOLDFINE ID, MADDUX BA, GRODSKY GM 2003: Are Oxidative Stress-Activated Signaling Pathways Mediators of Insulin Resistance and $\beta$-Cell Dysfunction? Diabetes 52: 1-8

FEILLET-COUDRAY C, ROCK E, COUDRAY C, GRZELKOWSKA K 1999: Lipid peroxidation and antioxidant status in experimental diabetes. Clin Chim Acta 284: 31-43.

FUSHIYA S, KISHI Y, HATTORI K, BATKHUU J, TAKANO F, SINGAB AN, OKUYAMA T 1999: Flavonoids from Cleome droserifolia suppress NO production in activated macrophages in vitro. Planta Med 65: 404-407

GUPTA MP, SOLIS NG, ESPOSITO M, SANCHEZ S 1984: Hypoglycemic activity of Neurolaena lobata (L). Ethnopharmacology 10: 323-327

KAKKAR R, MANTHA SV, RADHI J, PRASAD K, KALRA J 1998: Increased oxidative stress in rat liver and pancreas during progression of streptozotocin-induced diabetes. J Clin Sci 94: 623-632

KOSUGY H, KIKUGAVA K 1989: Potential thiobarbituric acid-reactive substances in peroxidized lipids. Free Rad Biol Med 7: 205-207

L. AL-SHAMAONY SM, KHAZRAJI AL, TWAIJI HA 1994: Hypoglycaemic effect of Artemnisia herbaalba II. Effect of a valuable extract on some blood parameters in diabetic animals. Ethnopharmacology 433: 167-171

MELANDER A 1988: Non-insulin dependent diabetes mellitus: treatment with sulphonylureas. In: NATTRASS, M, HALE, PJ: Clinical Endocrinology and Metabolism. Baillière-Tindall, London, pp. 443-453.

SANCHEZ-MORENO C, LARRAURI JA, SAURA-CALIXTO F 1998: A procedure to measure the antiradical efficiency of polyphenols. J Food Sci 76: 270-276

TIWAI AK, MADHUSUDAN RAO J 2002: Diabetes mellitus and multiple therapeutic approaches of phytochemicals: present status and future prospects. Curr Sci 83: 30-38

ZHANG HY, WANG LF 2002: Theoretical elucidation on structure-antioxidant activity relationships for indolinonic hydroxylamines. Bioorg Med Chem Lett 12: 225-227

WHO Expert Committee: Diabetes Mellitus. 2nd rep. Geneva, World Health Org., 1980 (Tech. Rep. Ser. 646) 
Plate III

El. Naggar et al.: Antidiabetic Effect ... pp. 347-352

Fig. 3. HPLC- UV spectra of the major flavonoids present in the extract. Each compared with its standard spectra using the same method.

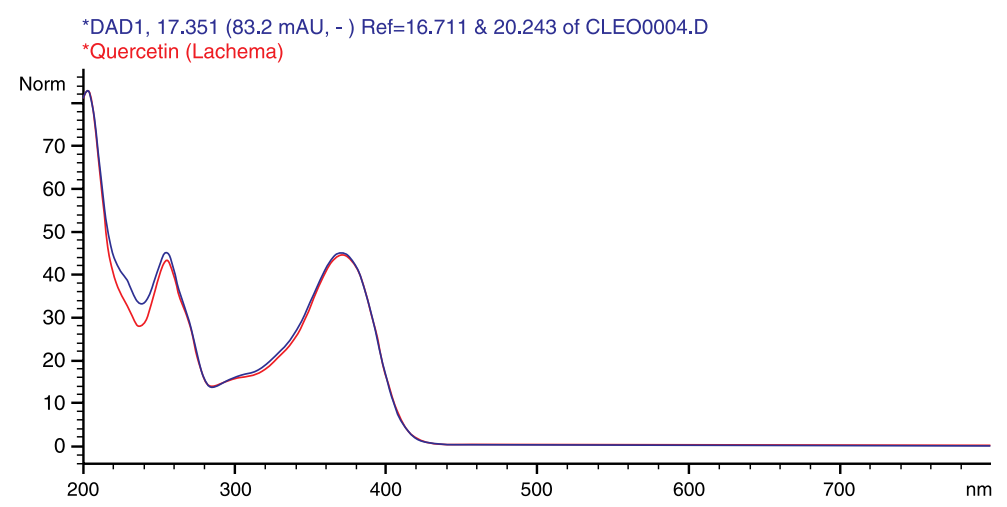

A. Quercetin at retention time $17.35 \mathrm{~min}$

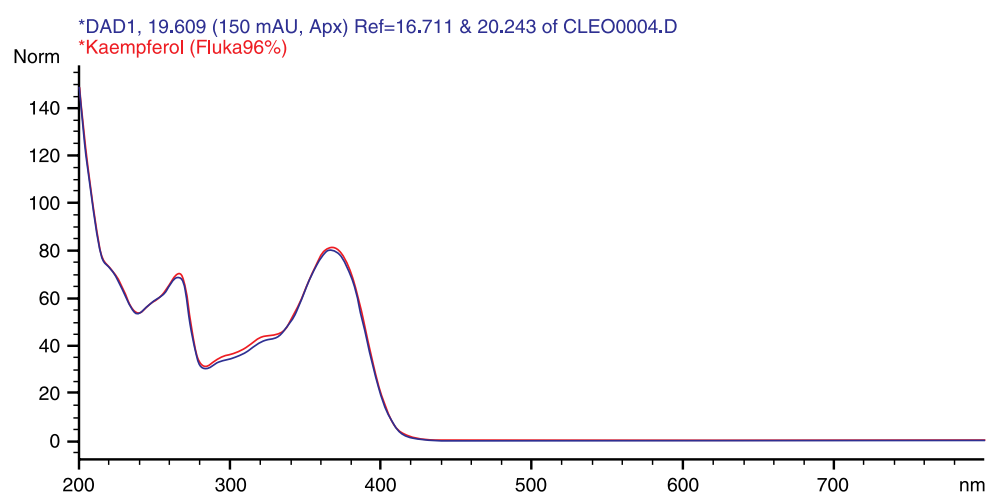

B. Kaempferol at retention time $19.61 \mathrm{~min}$

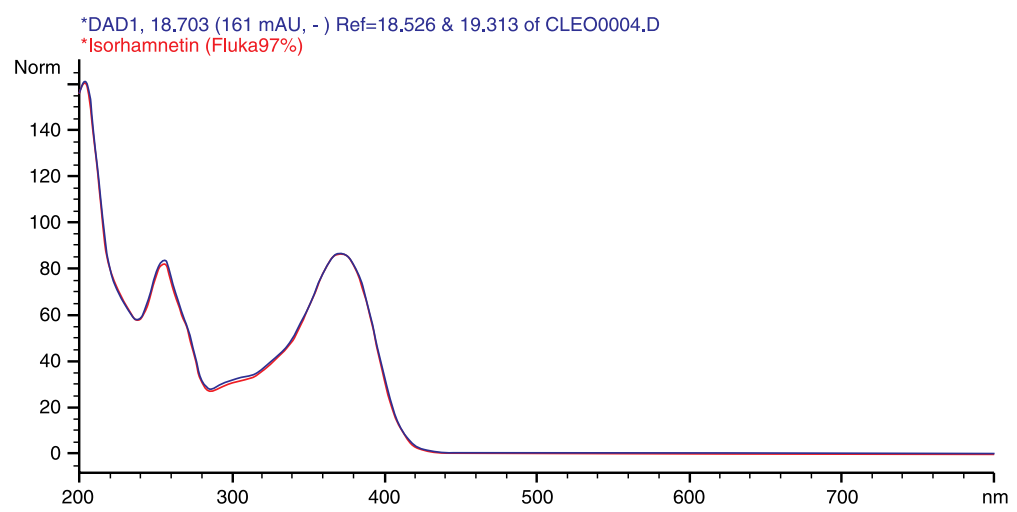

C. Isorhamnetin at retention time $19.06 \mathrm{~min}$ 
Plate IV

Fig. 4. HPLC- UV spectra of the major phenolic acids present in the extract. Each compared with its standard spectra using the same method.
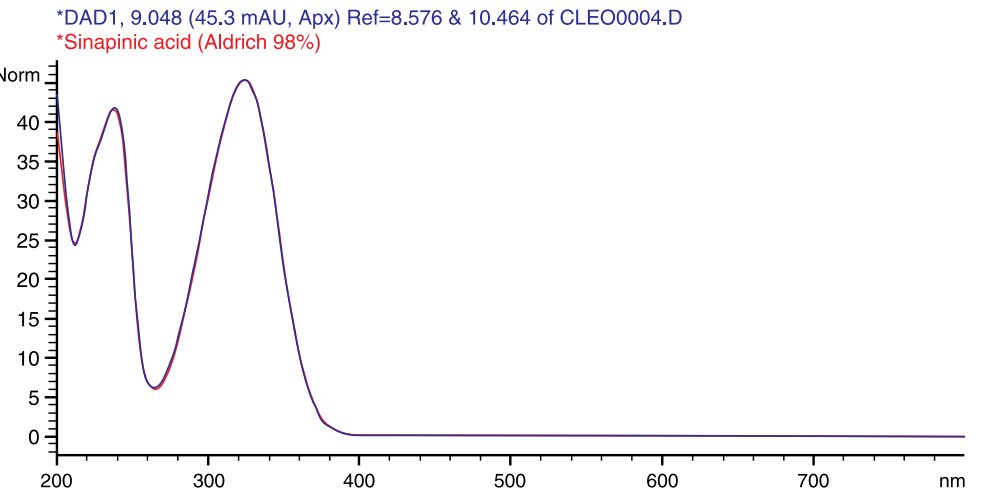

A. Sinapinic acid at $9.05 \mathrm{~min}$

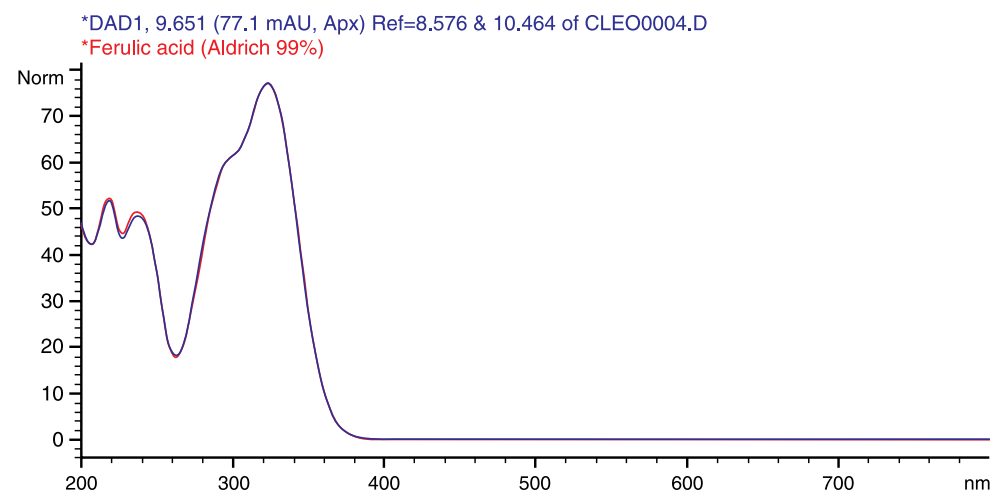

B. Ferulic acid at $9.65 \mathrm{~min}$

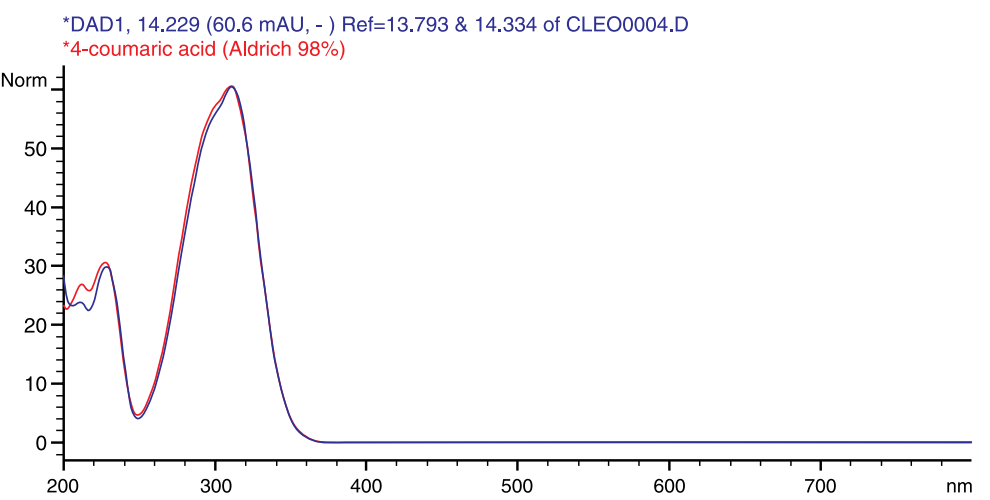

C. 4-coumaric acid at $9.9 \mathrm{~min}$ 